\title{
FUTURE OF REBALANCING POLICY UNDER TRUMP: A CASE FOR CONTINUITY
}

\author{
Younis Chughtai \\ Khurram Iqbal $^{* *}$
}

\begin{abstract}
Trump's foreign policy outlook and his rhetorical predispositions suggest that the American foreign policy is about to undergo drastic changes in terms of substance matter of policy. The arrival of Trump at the helm of affairs has built a conventional perception of gradual American retreat from the Obama's rebalancing policy and its pacific-centric outlook. Any abrupt change in this policy of rebalancing will have serious repercussions for the regional economic, political and security architecture designed by America since world-war II. In this context, Offensive Realism, that takes system level variables as the primary determinants of foreign policy of great powers, offers a valuable framework to understand and explain the future course of Obama's policy of rebalancing under the incumbent administration. To this end, this article is aimed at delving into the theoretical and historical reservoirs related to the US foreign policy along with the current practices of Trump administration to test the claims of continuity or transformation in the US foreign policy of rebalancing in the Asia Pacific region. This article asserts that Obama's rebalancing policy would continue in the future with certain tactical adjustments related to the implementation of policy.
\end{abstract}

Keywords: Trump administration, rebalancing, Asia Pacific, foreign policy, pivot to Asia

\section{Introduction}

America is considered to be a Pacific nation and besides this, contemporary regional realities have made this region (Asia Pacific) more important to America. Obama's policy of rebalancing included active US engagement in the region and resulted in realignment of diplomatic, economic and security imperatives in the Asia Pacific region to shape the regional environment in accordance with the supreme American interest of preserving its status as a sole regional hegemon on the face of earth. Skepticism about the Trump Administration's policy in the Asia Pacific is fuelled, in part, by rhetoric projecting American retreat from its commitments beyond the American continent, particularly in the Asia Pacific region. Describing the profound uncertainty regarding the U.S-Asia-Pacific relations under Trump administration, Mira Rapp-Hooper, an Adjunct Senior Fellow with the Asia-Pacific Security Program at CNAS (Center for a New American Security), observed that "although the concrete details of Trump's strategy for Asia are scant, one thing seems clear. An uncertain future awaits a region that has

\footnotetext{
*Younis Chughtai, Research Scholar, Islamabad Policy Research Institute (IPRI), Islamabad

${ }^{* *}$ Khurram Iqbal, Ph.D. Assistant Professor, National Defence University, Islamabad
} 
become accustomed to principled and mostly predictable US leadership". ${ }^{1}$ This uncertainty regarding the future of US-Asia Pacific policy, particularly the Obama's rebalancing policy, spurred interest in investigating and examining the US foreign policy in terms of theoretical and more practical (in the face of rhetoric and individual choices) grounds to explain the nature of US foreign policy choices and to provide new insights into the kind of foreign policy Trump administration may take in the future. This study briefly deconstructs the history of US Asia Pacific policy in the Post-Cold War era and theorizes the Obama's rebalancing policy to predict its fate under the Trump administration. It then strives to substantiate the argument by giving a brief analysis of incumbent administration's engagement with the Asia Pacific region.

\section{Historical Evolution of the Rebalancing Strategy}

At the advent of $21^{\text {st }}$ century, the status of America as a sole hegemon is significantly challenged in terms of shuffling in resident hierarchy of global power structure. Resurgence of Russia, rise of China and Japan as economic competitors to US' leading economic role are cases in point. In the post-Cold war era, different American administration including that of President Bill Clinton and President George W. Bush remain actively engaged in Asia Pacific region to shape the rise of regional powers in accordance with the broader American regional and global interests. In this wake, the Clinton administration, for instance, promulgated a "New Pacific Community Initiative" in 1993, a platform envisaged with as a platform to forge liberalization of trade and economic integration in the region. ${ }^{2}$ Adding to this, President Clinton, in 1995, worked to normalize relations with Vietnam. President Clinton strived to adopt a policy that would engage and check China simultaneously. ${ }^{3}$

Following the footsteps of his predecessor, the Bush Administration further augmented US relations with its allies and other friendly countries in the region. For this purpose, to ensure and strengthen bilateral cooperation with Indonesia, administration signed an agreement with Indonesia in 2001 and Philippines and Thailand were given the status of major non-NATO allies, in 2003. Furthermore, to promote liberalization of trade, freetrade agreements were signed with Singapore, Australia and South Korea in 2003, 2004 and 2007 respectively. Adding to this, negotiations were carried out with several countries for a multi-lateral framework, the Trans-Pacific Partnership (TPP), in 2008. In another major development, a 10-year defence cooperation agreement was sanctioned with India in 2005, establishing a new "global partnership" and a strategic connection with India to check the rise of China in the region. ${ }^{4}$

\footnotetext{
${ }^{1}$ Rapp-Hooper, Mira. "Deciphering Trump's Asia Policy." Foreign Affairs. November 22, 2016, https://www.foreignaffairs.com/articles/asia/2016-11-22/deciphering-trumps-asia-policy, Accessed July 24, 2017.

${ }^{2}$ U.S Department of State, "History of the Department of State During the Clinton Presidency (1993-2001)." accessed July 26, 2017, https://2001-2009.state.gov/r/pa/ho/pubs/8530.html.

${ }^{3}$ Joseph Nye, "Our Pacific Predicament," The American Interest, Vol. 8, No. 4, (March/April 2013).

${ }^{4}$ Robert Sutter, Michael E, Brown et al., Balancing Acts: The US Rebalance and Asia-Pacific Stability

(Washington, DC: Sigur Center for Asian Studies \|| Rising Powers Initiative, 2013), p-5.
} 
Faced with the changed political and strategic dynamics of global political sphere, professed relative decline of America and China's assertiveness in Asian hemisphere Obama administration came up with a comprehensive framework or a strategy named as "Pivot to Asia" to engineer economic, political and strategic architecture of Asia Pacific region. Asia has remained priority of the US foreign policy endeavours right from the day one of the Obama administration. ${ }^{5}$ However, the instruments and tactics of the strategy have changed over time to conform the constant substance of policy to the economic, political and strategic dynamics of regional and global environment. Earlier, during 2009, it was primarily directed towards the phenomenon of responsible sovereignty, power cooperation and international order based on rules and norms. ${ }^{6}$ During 2010, American Pivot policy was about "competition over the spheres of influence". ${ }^{7}$ In 2011, the word pivot was officially adopted in US foreign policy statements. It refers to a strategic shift that includes substantial shift of US diplomatic, economic, strategic, and other investments from other avenues to the Asia-Pacific region. ${ }^{8}$ Considering the concerns of allies in other regions, in late 2011 and 2012, "Rebalance" was introduced into the American foreign policy statements, replacing the word "pivot", and is considered to be more inclusive. Tom Donilon, National Security Advisor to President Obama, elaborated rebalancing of priorities and identified the strategy that included an intensified American role in Asia-Pacific. ${ }^{9}$ Besides these shifts in American response to rising China, trade-off between different components of rebalancing strategy was seen during the times of Obama administration. Earlier in 2011, when the policy of rebalancing was first disclosed, military aspect of the strategy was primarily emphasized. China was concerned about these endeavours, and Beijing came forward to project its power in terms of SouthChina sea dispute with US allies. The Obama administration revisited and then recalibrated its approach in late 2012 by reducing the emphasis over military component of the strategy and focusing more on economic and diplomatic elements. In this readjusted strategy, Obama administration called for closer US engagement with China. At the end of the Obama's stay in the office, he visited Asia, in September 2016, where he attended G-20 summit, had a meeting with Chinese premier, and headed to Laos, making the last push of his presidency to rebalance Washington's foreign policy towards Asia. $^{10}$

Obama was then replaced by the president Trump. According to conventional wisdom, Trump's foreign policy agenda, if acted upon, would move away from post-cold war US foreign policy trajectory towards the Asia Pacific region. The rhetoric of "America First"

\footnotetext{
${ }^{5}$ Hillary Clinton, “America's engagement in Asia-Pacific," Honolulu, Hawaii, October 28, 2010 , http://still4hill.com/2010/10/28/hillary-clinton-americas-engagement-in-the-asia-pacific/., Accessed July 25, 2017.

${ }^{6}$ Jones, Pascual and Stedman, eds. "power and responsibility: Building International Order in an Era of Transnational Threats," (Washington, DC: Brookings Institution, 2009), pp-42-44.

${ }^{7}$ U.S State Department of State, "Remarks on Regional Architecture in Asia: Principles and Priorities," http://www.state.gov/secretary/20092013clinton/rm/2010/01/135090/. Accessed August 2, 2017.

${ }^{8}$ Hillary Clinton. “America's Pacific Century.” Foreign Policy November, 2011, http://foreignpolicy.com/2011/10/11/americas-pacific-century/, Accessed August 7, 2017.

${ }^{9}$ Tom Donilon, "America Is Back in the Pacific and Will Uphold the Rules," Financial Times, November 27, 2011. https://www.ft.com/content/4f3febac-1761-11e1-b00e-00144feabdc0, Accessed July 25, 2017.

${ }^{10}$ Robert Sutter, Michael Brown et al., Balancing Acts: The U.S. Rebalance and Asia-Pacific Stability (Washington, DC: Sigur Center for Asian Studies || Rising Powers Initiative, 2013),,pp.5-8
} 
and "Making America Great Again" holds the connotations of American withdrawal from its commitment to the liberal world order and to its allies in the region. Trump rolled out this view in an address delivered at the Center for the National Interest, a Washington D.C. based think tank, on April 27. Trump rejected American foreign policy in the post-cold war era as directionless and ineffective. He asserted that he would narrow his focus down towards rebuilding America's military and economy to formulate a "new rational American foreign policy". ${ }^{11}$

Moreover, President Trump's refusal to explicitly endorse its commitment to the Article 5 of North Atlantic Treaty Organization's founding document, Trump's bashing of Japan, whom he sees as ungrateful freeloaders, as a source of weakening American economy and his decision to withdraw from Paris Climate accord joining Syria and Nicaragua as the only countries not party to the Paris agreement has raised serious doubts about America continuing its long term alliance commitments in Asia Pacific region. Apparently, it seems to signal an uncompromised departure away from primary agenda of Obama's rebalance to Asia.

\section{Theoretical Framework}

In order to understand and predict the future trajectory of US foreign policy behaviour towards any region, particularly Asia Pacific region, it is very important to analyse it through a theoretical perspective. Theory explains foreign policy phenomenon and outlines what is expected to unravel in the future, given the careful understanding of given factors or variables. Theory helps us to understand the complexities of social and political world we live in. According to John J. Mearsheimer, "some are aware of it and some others are not, some admit it and some do not; but there is no escaping the fact that we could not make sense of the complex world around us without simplifying theories." 12

For the sake of this study, an offshoot of system level theory i-e offensive realism is used. This theory partially delivers the promise to explain American foreign policy in terms of its quest for sustaining its status as a sole regional hegemon. Consistent to this framework, Nicholas J. Spykman, an American political scientist, also articulated the need of offensive American foreign policy behaviour towards other regions to sustain and secure its status as a sole regional hegemon on earth". ${ }^{13}$

Some important assumptions and propositions of this theoretical framework are: (1) anarchy is primary character of international structure therefore, conflict is inevitable, (2) security is scarce in the anarchic international structure, (3) great powers possess some offensive military capabilities that can be used to cause damages or even destroy each other' (4) suspicion of great powers towards the intentions of competing powers, (5) survival as central to the objectives of every great power, sometimes states can also

\footnotetext{
${ }^{11}$ National Interest. "Trump on foreign policy." http://nationalinterest.org/feature/trump-foreign-policy-15960, Accessed July 30, 2017.

${ }^{12}$ Mearsheimer, J. M, “The tragedy of great power politics," (New York: W.W. Norton and Company, Inc, 2001), p.10.

${ }^{13}$ Spykman, N. J., “American's strategy in world politics: The United States and the balance of power," (NewBrunswick: Transaction Publishing, 2007), p-457.
} 
pursue non-security goals as long as the requisite behaviour does not conflict with the balance-of- power logic, (6) regional hegemony is the primary goal of any state, whereas ultimate goal is to secure the status of global hegemon (7) to achieve the status of global hegemon, state adopt the strategy of offshore balancing to prevent the emergence of any other competing hegemon, (7) the strategy of offshore balancing can be utilized either through buck-passing or through direct balancing strategy and (8) states as rational actors. ${ }^{14}$

John J. Mearsheimer, explains the quest of America to sustain and maintain its status as a sole regional hegemon around the globe by stating that, "the USA is the only great power that has achieved the status of regional hegemon. As a regional hegemon, the primary goal of the USA is to maintain the status quo of the international system and prevent the emergence of a competitor regional hegemon" $" 15$. Therefore, we can reasonably argue that offensive realism can aptly predicts the future course of US foreign policy in the AsiaPacific region.

Considering the scope of this study, three variables proposed by offensive realism are utilized to build the argument: (1) supremacy doctrine of foreign policy as a tool to explain the superiority of strategic interests over non-strategic interests, (2) use of offshore balancing strategy to prevent the rise of potential challenger in other regions and (3) minimal role of individual preferences and ideological rhetoric in the face of primary interest of survival.

Seeing the tenuous approach of the Trump administration, particularly towards their policy towards Asia, one is left with the two sources of material on which one can draw his/her analysis. The first is the Administrations' engagement with the Asia pacific region actors during first eight months of their stay in Oval office; the second is the writings of Trump's closest national security advisers.

\section{Determinants Shaping the Policy of Previous Administrations}

According to the offensive realist school of thought, system level factors are primarily important in shaping the foreign policy behaviour of any state. Post-cold war era, marked with several developments including potential rise of regional powers, increasing prospect of nuclearisation in the region and several other non-security threats, has seen a consistency in pattern of system level factors that dictated US response to the changing regional and global realities.

The active engagement of Obama and the previous post-cold war administrations in the Asia Pacific region was a reaction to anarchic international structure of which the regional powers, particularly China, could take advantage. There was no supranational authority to resolve the inter-state disputes. The creation of International organizations, particularly United Nations in 1945, didn't bring any significant change to international

\footnotetext{
${ }^{14}$ Prifti, Bledar, "U.S foreign policy in the Middle East: A case for continuity," (London: Plagrave Macmillan, 2017), pp-50-51.

${ }^{15}$ Mearsheimer, tragedy of great power, pp-46-47.
} 
structure as it was too weak to deal with strategic issues involving major powers, happened to be its donors as well. ${ }^{16}$

In light of assumptions of offensive realism, the second factor that influenced the US behaviour in the region was the increasing relative power, whether economic or military, of regional powers, mainly China, that could inflict two damages on the US foreign policy objectives: (1) could disrupt the balance of power in the region and (2) could cause harm to the other geopolitical and geoeconomic interests of US in the region.

As guided by the offensive realism lens, the third factor that contributed to the US response to the developments in the region was the suspicion and fear that the increasing capabilities and assets of China are being built in offensive terms and China is intended to challenge the existing world order. Certain Chinese actions have endorsed American perception of China as a revisionist power. Offensive posturing of China to respond to its disputes with Vietnam, Philippines, and other Southeast Asian neighbours over the South China Sea was regarded as challenge to US position in the region. Moreover, several incidents of nasty clashes between Chinese vassals and ships of Vietnam and Philippines, in 2012, further fuelled the tensions. ${ }^{17}$

The fourth factor that directed US foreign policy in the region was the increasing prospects of nuclear proliferation in the region. ${ }^{18}$ North Korean nuclear-weapon program and its confrontational rhetoric, along with China's attempt to modernize its military muscles, posed significant challenge to US interests in the region. In the face of NorthKorean aggression and growing Chinese assertiveness, South Korea and Japan, traditional US allies, could also strive for the nuclear weapons to ensure there security on their own. At that time, US was required to reassure its allies of its security commitments through an active engagement in the region.

The fifth and the most important factor as proposed by the offensive realism was the survival of the state. ${ }^{19}$ Rogue behaviour of North Korea and increasing assertiveness of China in East and South China Sea somehow appeared as fostering existential threats to American survival. ${ }^{20}$ All these above mentioned factors largely contributed in shaping offensive and proactive American foreign policy in the Asia Pacific region under the previous administrations.

\section{A Case for Trump Administration}

To understand the future path of the rebalancing strategy under Trump administration, one needs to investigate the regional and international realities under which Trump administration is supposed to formulate its foreign policy towards the region. In this

\footnotetext{
${ }^{16}$ Prifti, US foreign policy, pp-64-65.

${ }^{17}$ Stars and Stripes. "Chinese aggressive tactics turning off Asian neighbours." https://www.stripes.com/china-s-aggressive-tactics-turning-off-asian-neighbors-1.226581\#.WaKATCgjHIU, Accessed July 27, 2017.

${ }^{18}$ This is author's assertion

${ }^{19}$ Mearsheimer, tragedy of great power politics, pp-33-34.

${ }^{20}$ Author's assertion
} 
context, the regional and international environment in the sense of five factors that have been already cited to delve into foreign policy of Obama and other post-cold war administrations will be discussed subsequently.

Like in the case of previous administrations, anarchy still persists in the international community of states. There is no global government to prevent the disruption of balance of power in the Asia Pacific region. In a tweet on August 27, 2016, Trump stated that "The United Nations has such great potential but right now it is just a club for people to get together" ${ }^{21}$.

In resemblance to the previous administrations, regional powers still possess economic and military capabilities that can damage American interests in the region. According to the late draft of the annual report issued in November 2016, by the US-China Economic and Security Review Commission, "China is building military capabilities to deal with hostile air, surface, and subsurface operational environments in the 'far seas'. Given its enhanced strategic lift capability, strengthened employment of special operations forces, increasing capabilities of surface vessels and aircraft, and more frequent and sophisticated experience operating abroad, China may also be more inclined to use force to protect its core interests," the report says. ${ }^{22}$ According to the official Xinhua news agency, the military budget of China, for 2017, will increase by 7 per cent, to 1.044 trillion Yuan (\$151.43 billion). ${ }^{23}$ Beside this, North Korea's successful test of intercontinental ballistic missiles, in July 2017, has significantly added to this phenomenon.

As part of the determining factors in the previous administrations, suspicion towards Chinese rise still continues to exist under Trump administration. Throughout the heated 2016 presidential campaign, Trump vowed to label China a currency manipulator "on Day One," saying they were "killing" Americans on trade by keeping the Yuan artificially low and boosting exports. In furtherance to this, Chinese assertiveness in South China, its march towards Europe in terms of One Belt, One Road, and Chinese mechanism of regional integration, Regional Comprehensive Economic Partnership (RCEP), known as a replacement to Trans-Pacific partnership were suspected by US as an outcome of Chinese revisionist tendencies. ${ }^{24}$ Chinese military modernization and its denial of rule based international setting in South China Sea have further added to the phenomenon.

Existential threat coming from the Asia Pacific region has become more real and more intense under the Trump Administration in relation to the previous post-cold war administrations. North Korea's obtainment of ICBMs and their explicit designs to target

\footnotetext{
${ }^{21}$ Independent. "Donald Trump dismisses the United Nations as a club of people to "have a good time.", http://www.independent.co.uk/news/world/americas/donald-trump-united-nations-club-have-good-time-barackobama-israel-settlements-a7496786.html, Accessed July 27, 2017.

${ }^{22}$ U.S-China economic and security review commission. "USCC 2016 annual report." last updated November 2016.

https://www.uscc.gov/sites/default/files/annual_reports/2016\%20Annual\%20Report\%20to\%20Congress.pdf, Accessed August 12, 2017.

${ }^{23}$ Reuters. "China confirms 7 per cent increase in 2017 defence budget." http://in.reuters.com/article/chinaparliament-defence-budget-idINKBN16D0FU, Accessed August 4, 2017.

${ }^{24}$ Reuters. "China backed trade pact playing catch-up after U.S led TPP deal." http://www.reuters.com/article/us-trade-tpp-rcep-idUSKCNOS500220151011, Accessed August 6, 2017.
} 
Guam, sometimes known as American "permanent aircraft carrier" and "Pacific spear tip", poses an existential threat to the American security. Before the acquisition of ICBM, during the previous administrations, America was facing a second level threat from North Korea that could be neutralized through "buck passing" strategy. ${ }^{25}$ But now, when America is facing a first level existential threat from North Korea, direct balancing strategy seems more optimal.

In light of the whole discussion, it can be argued that, influenced by the similar system level variables, rebalancing strategy is more likely to be continued in the foreseeable future. The continuity in the foreign policy would be the result of unchanged nature and composition of system level variables and unaltered status of US as a sole regional hegemon on the face of earth.

\section{Trump's Peace through Strength and Obama's Re-balancing - A Comparison}

The tactical elements (means used to pursue any foreign policy goal) of each presidential foreign policy outlook are not counted so much to claim continuity or discontinuity in foreign policy. Strategic objectives of each Administration and factors that dictate those objectives are relatively more crucial in this regard. A critical evaluation and comparison of Trump's peace through strength towards Asia Pacific and vision of Obama's rebalancing strategy will test the claims about the continuity or transformation in US foreign policy.

Although there is no single source framing the US rebalancing strategy toward Asia, however, US policymakers have identified its multiple contours explicitly through speeches and public remarks, and implicitly through its visible behaviour in the region. According to the report issued by Bureau of Budget and Planning, on April 2, 2014, the vision of US rebalance under Obama was aimed at achieving multiple goals which included: (1) reassurance to the allies of US' alliance commitments, (2) increasing US role in shaping more mature economic and security architecture in the Asia-Pacific region, (3) Maintaining peace and security across the Asia-Pacific region and (4) supporting trade liberalization and economic development in the region. ${ }^{26}$

To achieve this vision, US policymakers have advanced three initiatives: (1) Military, (2) Economic and (3) Diplomatic. Military component of the strategy included broader distribution of forces, increased flexibility accompanied by rotational deployments and enhancing partners' capabilities through more flexible security assistance mechanisms. ${ }^{27}$ In addition to this, diplomatic element of rebalancing strategy was aimed at strengthening US alliance setting in the region, building deeper relationships with emerging partners, effective engagement with Asia-Pacific multilateral institutions and reaffirming China-

\footnotetext{
${ }^{25}$ New York Post. "North Korea threatens 'merciless strike' on US." http://nypost.com/2017/08/20/north-koreathreatens-merciless-strike-on-us/, Accessed August 20, 2017.

${ }^{26}$ US Department of State. "Strategic Goal 2: Objective 2.2 - Rebalance to the Asia-Pacific through Enhanced Diplomacy, Security Cooperation, and Development." https://www.state.gov/s/d/rm/rls/dosstrat/2014/html/225797.html. Accessed August 8, 2017.

${ }^{27}$ Mark E. Manyin et al., "Pivot to the Pacific? The Obama Administration's 'Rebalancing' Toward Asia," (Washington D.C Congressional Research Service, March 28, 2012).
} 
US cooperative ties. Lastly, economic component of the strategy encompassed close American economic interaction and integration with Asia's growing economies and its active engagement with the region through multilateral groupings in the face of growing concerns that the United States could be excluded from an emerging, more-integrated and growing Asian economic framework. ${ }^{28}$

Obama remained affirmed to the notion of rebalancing until the end of his stay in office. He visited Asia, in September 2016, to further consolidate and complement the gains of rebalancing strategy. ${ }^{29}$ Followed by this, during the presidential campaign, in 2016, Trump's Asia advisors, Peter Navarro and Alexander Gray, wrote an article titled "Donald Trump's Peace through Strength Vision for the Asia Pacific: How the Republican nominee will rewrite America's relationship with Asia", and made an attempt to address the question of future trajectory of Obama's rebalancing strategy. ${ }^{30}$

This article reflects one important aspect that the substance of policy, shaping the rise of China in accordance with the American interests and managing the balance of power in the region, is more likely to remain similar in the future. But the mechanism to implement the policy will take a different course. In the words of Peter Navarro and Alexander Gray, "President Barack Obama's administration was right to signal reassurance to our Asian allies and partner, later on, this pivot has turned out to be an imprudent case of talking loudly but carrying a small stick, one that has led to more, not less, aggression and instability in the region". ${ }^{31}$ Substance of the policy was hardly criticized in this article by the authors. According to the advisers, stability, prosperity and security are the core objectives of American foreign policy. These aforementioned goals have shaped the essence of rebalancing strategy. However, advisors have focused more on denouncing the flawed implementation of the policy and incompatibility of means adopted with the substance of the policy. In their opinion, military strategy was aimed at allocating the additional resources to the defence and strengthening the military posture of America in the region; however, the real evidences tell the different story. As former Air Force Secretary Mike Wynne has warned: "Under the Obama administration, the Navy has shrunk to its smallest size since World War I. The Army is the smallest it has been since before World War-II. The Air Force is the smallest in its history, and its aircraft are the oldest". 32

According to the advisors, diplomatic component of rebalancing strategy also faced certain setbacks under Obama administration, as it is stated that "American allies and partners in the region have been disheartened by a foreign policy that has veered from feckless to mendacious". They have mentioned the US' gross treatment of Taiwan,

${ }^{28}$ Sutter, Balancing Acts, 13-15.

${ }^{29}$ NBC news. "Analysis: In his final visit to region, Obama pushes Asia 'Pivot", https://www.nbcnews.com/news/us-news/analysis-final-visit-region-obama-pushes-asia-pivot-n644981. Accessed August 3, 2017.

${ }^{30}$ Peter Novarro and Alexander Gray. "Donald Trump's Peace through Strength Vision for the Asia Pacific: How the Republican nominee will rewrite America's relationship with Asia." Foreign Policy Magazine, http://foreignpolicy.com/2016/11/07/donald-trumps-peace-through-strength-vision-for-the-asia-pacific/ Accessed August 1, 2017.

${ }^{31}$ Ibid.

${ }^{32}$ Ibid. 
Philippines' high-profile rejection of American leadership and Thailand's increasing cooperative ties with China to substantiate their argument.

In their viewpoint, TPP, one of the core pillar of US' economic engagement in the region, is not helping American economy to grow. According to a report, issued in January 2016, by Global Development and Environment Institute at Tufts University, "the Trans-Pacific Partnership (TPP) will cause labour's share of income to decline by 1.3 per cent, increasing inequality in the United States". ${ }^{33}$ In furtherance to this, the economists quoted, "the 12-nation Pacific Rim trade deal will likely lead to the loss of 448,000 jobs from the US workforce, while lowering GDP by more than a half-percentage point over the next decade". ${ }^{34}$

Peter Navarro and Alexander Gray put forth a different roadmap to implement the already defined substance of rebalancing strategy. They presented a strategy of "speaking softly and carrying a big stick", a postulate of Reagan's doctrine, to pursue American interests in the Asia Pacific region. They have talked about expanding the US naval power in the region, burden sharing with allies having powerful economies and reassuring allies through the actions, rather than rhetoric, of the administration. The two advisers emphasized honouring the US commitments of Asian alliances as bedrocks of stability in the region. From adviser's standpoint, nothing would be pursued at the expense of American economy because American economy is central to sustaining an effective military and diplomatic presence in the region. ${ }^{35}$

Therefore, it can be said that Trump's peace through strength has nothing to do with the substance or the strategic objectives of the rebalancing strategy rather it is more focused towards the change in means or strategic tools being used to pursue the foreign policy objective. It can be concluded that US foreign policy is very less likely to experience any abrupt transformation in terms of its strategic objectives and foreign policy tools unless there is any significant change in the nature and composition of system level variables.

\section{Individual Preferences and Foreign Policy Choices}

During the presidential campaign, the incumbent president has promised to bring drastic changes in the foreign policy, focusing it more on economic interests, making it more protectionist one and moving away from previous foreign policy outlook. To understand the impact of individual ideological preferences on US foreign policy, the foreign policy of two previous presidents, Jimmy Carter and Barack Obama will be investigated to predict the future of US foreign policy in the Asia Pacific region in the face of Trump's rhetoric.

President Carter won the election on the grounds of bringing tough changes to US foreign policy, directing it more towards Human Rights issues, peace initiatives and a more

\footnotetext{
${ }^{33}$ Global Development and Environment Institute at Tufts University. "Trading Down: Unemployment, Inequality and Other Risks of the Trans-Pacific Partnership Agreement."

http://www.ase.tufts.edu/gdae/Pubs/wp/16-01Capaldo-IzurietaTPP_ES.pdf , Accessed July 25, 2017.

${ }^{34}$ Ibid.

${ }^{35}$ Novarro and Gray, Peace through Vision.
} 
liberal centric. During the presidential election campaign, Jimmy Carter called for increasing role of "morality" in American foreign policy. He also promised that he would withdraw his ground forces from South Korea. ${ }^{36}$ Despite all these preferences, developments in the international system and dynamics of security and survival had compelled President Carter to reinstate a realist based foreign policy. Carter doctrine, promulgated during a speech delivered before Congress, on January 23, 1980, didn't reflect any of the promises made by the president during the presidential campaign. President Carter stated in his speech that "I'm determined that the United States will remain the strongest of all nations, but to be secure we must face the world as it is". ${ }^{37}$ In addition to this he highlighted three major global events as challenges to US foreign policy: (1) Soviet adventures in military terms across the globe, (2) disadvantageous position of western world in terms of supply of hydrocarbon resources and (3) social and political transitions in different parts of the world. ${ }^{38}$ Moreover, despite Carter's goals of absolute withdrawal from South Korea, during his time in office he only brought about 3,000 US troops home. In light of these arguments, it can be asserted that ideology more often succumbs to the constraints of system level variables and individual preferences related to non-strategic interests fail to prevail in the face of issues of national security.

"Change we can believe in", based on this slogan, Barack Obama stood victorious in the 2008 presidential election. After a challenging period in US foreign policy under Bush administration, Barack Obama promised some radical changes in US foreign policy. ${ }^{39}$ However, the foreign policy conduct was opposite to what was claimed during the presidential campaign. Indeed, far from wholesale reversal, Obama has failed to bring any substantial change in U.S foreign policy and in fact he reinstated the strategies of Bush Administration. ${ }^{40}$ Even though certain tactical adjustments were adopted but both Bush and Obama share abstract grounds that entailed their foreign policy behaviour: primacy of American national interests, the US role as global hegemon, and focusing on war against terrorism. ${ }^{41}$

After a year in office, ideological outlook of Obama failed to prevail against the regional and global constraints, for instance, Obama stated in 2009: "I face the world as it is. Negotiations cannot convince al Qaeda's leaders to lay down their arms. So yes, the instruments of war do have a role to play in preserving the peace. War is sometimes necessary" ${ }^{42}$ This statement actually reinforces the idea that whenever any national

${ }^{36}$ The New York Times. "Carter with a Long List of Campaign Promises, Now Faces the Problem of Making Good on Them." http://www.nytimes.com/1976/11/15/archives/carter-with-a-long-list-of-campaign-promisesnow-faces-the-problem.html. Accessed August 12, 2017.

${ }^{37}$ The American Presidency Project. "The State of the Union Address Delivered Before a Joint Session of the Congress. January 23, 1980”, http://www.presidency.ucsb.edu/ws/?pid=33079. Accessed August 13, 2017.

${ }^{38}$ Ibid.

${ }^{39}$ Singh, R. 'Continuity and Change in Obama's Foreign Policy', in Rockman, B. A., Rudalevige, A. and Campbell, C. eds. The Obama Presidency: Appraisals and Prospects. (Washington, DC: CQ Press, 2012), p268-295.

${ }^{40}$ Singh, R. Barack Obama's Post-American Foreign Policy: The Limits of Engagement. (London: Bloomsbury Academic, 2012), p-11-12.

${ }^{41}$ Hemmer, C. "Continuity and Change in the Obama Administration's National Security Strategy", (UK: Comparative Strategy, 2011) 268-277. DOI: 10.1080/01495933.2011.587685.

${ }^{42}$ NDTV. "Text of Obama's speech after accepting Nobel prize." http://www.ndtv.com/world-news/text-ofobamas-speech-after-winning-nobel-prize-402922. Accessed August 15, 2017. 
security interest conflict with the ideological predisposition of individual leaders, national security interests always prevail.

From this discussion, it can be argued that individuals operate under specific international strategic and political context that constrains their foreign policy preferences and direct them to act and behave in a certain way. Therefore, it can reasonably be asserted that President Trump's rhetoric is less likely to bring any substantial change, at abstract level, to the foreign policy of America in the Asia Pacific region.

\section{Incumbent Administration's Engagement with Asia Pacific}

Trump Administration's interactions with the different regional (Asia Pacific) actors and its efforts at diplomatic, economic and military level also provide new insights into the kind of Asia policy Trump Administration may take in the future.

James Norman Mattis, Trump's secretary of the defence, spoke at Shangri-La Dialogue (SLD), June 2017 and offered some more meaningful indications of where the administration may be headed in the near future. The speech was mainly focussing on three broader areas: 1) framing US policy within the rule based order, 2) Challenges for security and stability in the region and 3) outlining the strategies US would take in the future. The strategic approach contoured by Mattis included: 1) working for a constructive, results-oriented relationship with China, 2) Strengthening alliances, 3) empowering countries in the region to shape more stable security and economic architecture and 4) strengthening US military capabilities in the region. ${ }^{43}$

However, the parameters outlined by James Mattis are markedly similar to those given by the Ash Carter, Obama's Secretary of Defence, during his speech at San Diego California, on September 29, 2016. Carter listed the three phases of the rebalance that had been undertaken by the Obama administration: (1) enhancing the US military's force posture in vast Asia Pacific region, (2) modernizing America's relationship its allies and (3) catalysing the region's principled and inclusive security network.

Moreover, Mattis reaffirmed the importance of Asia Pacific region for America as he said, "Five United States' states, including my home state of Washington, have Pacific Ocean shorelines. The United States is a Pacific nation in both geography and outlook. From my first trips as Secretary of Defence, and from Vice President Pence's first trip, Secretary of State Tillerson's trips, the American administration is demonstrating the priority we place on relationships in the Asia-Pacific region, a priority region for us". ${ }^{44}$

Furthermore, considering the intensity of real and direct threat posed by North Korea and China's rigid stance over South China Sea, Mattis put relatively greater emphasis on North Korea and China's rise in his list of challenges, including a much brusque statement on China's position in South China Sea. Mattis stated, "We oppose countries

${ }^{43}$ U.S. Department of Defence. "Remarks by Mattis at Shangri-La Dialogue." Accessed August 6, 2017, https://www.defense.gov/News/Transcripts/Transcript-View/Article/1201780/remarks-by-secretary-mattis-atshangri-la-dialogue/.

${ }^{44}$ Ibid. 
militarising artificial islands and enforcing excessive maritime claims unsupported by international law. We cannot and will not accept unilateral, coercive changes to the status quo. We will continue to fly, sail and operate wherever international law allows, and demonstrate resolve through operational presence in the South China Sea and beyond". 4 Consequently, it can be asserted that the policy line of Mattis, a key member of Trump administration, reflects the continuity of rebalancing strategy under the incumbent administration as well.

Considering all these activities of Trump administration that reflect more assertive and more active positioning of America in the Asia pacific region, the continuity of Obama's rebalancing with slight tactical adjustments seems more optimal. These recent developments have further substantiated the theoretical assumptions of offensive realism that tend to argue in favour of continuity of rebalancing strategy. Suffice to say that given the nature of diplomatic, strategic, and military efforts done by Trump Administration, since January, 2017, it is justifiable to argue that Trump administration is more likely to adopt the substance matter of rebalancing strategy with certain tactical adjustments.

\section{Conclusion}

This article argued that rhetorical predispositions and ideological preferences of President Trump are less likely to bring any substantial transformation in US policy of rebalancing in Asia Pacific region. Systemic constraints, as proposed by offensive realism, play crucial role in shaping foreign policy of major powers. These systemic determinants, under the Trump administration, have turned more supportive of the rebalancing policy of predecessor government. Considering the flaws of Obama administration in terms of implementation, rather than substance of policy, as criticized by Peter Novarro and Alexander Gray, Trump administration is expected to bring certain changes in terms of implementation of policy, which may include more emphasis on strengthening the military posture of US in the region. Other pillars of Obama's rebalancing which include: active engagement in the region, reassurance to allies of US' security commitments, shaping the rise of potential challengers and elimination of threats coming from the region are expected to be pursued more effectively and with more assertiveness. This persuasion can widely be seen throughout the current administration's engagement with the Asia Pacific region countries.

\footnotetext{
${ }^{45}$ Ibid.
} 